\title{
Account of a Roman Villa Discovered at Colerne, in the County of Wilts
}

\section{Edward William Godwin}

To cite this article: Edward William Godwin (1856) Account of a Roman Villa Discovered at Colerne, in the County of Wilts, Archaeological Journal, 13:1, 328-332, DOI:

10.1080/00665983.1856.10851013

To link to this article: http://dx.doi.org/10.1080/00665983.1856.10851013

册 Published online: 10 Jul 2014.

Submit your article to this journal $\widetilde{ }$

Q View related articles $\asymp$

4 Citing articles: 1 View citing articles 진 
ACCOUNT OF A ROMAN VILLA DISCOVERED AT COLERNE, IN THE COUNTY OF WILTS.

THE remains of the Roman villa, which form the subject of this paper, are situated in a field called the Allotment, in the parish of Colerne, Wiltshire, about six miles N.E. of Bath, and about half a mile E. from the Fosse way.

Eighteen years since (in 1838), some men, whilst ploughing in this field, accidentally struck upon a pavement which the occupier of the land, Mr. James Perren, immediately caused to be exposed ; finding, however, that neither the owner of the field, nor any gentleman in the neighbourhood, took any interest in the discovery, the remains were, after a short time, covered up, and unfortunately without any drawing or notes being taken. As soon as I became acquainted with these circumstances, I communicated them to my friend, the Rev. Gilbert Heathcote, vicar of the parish, in whom I found a most ready and liberal coadjutor, and having obtained permission of the present occupier, Mr. Frederick Perren, we commenced digging upon the 10th of October, 1854. At about nine inches below the surface of the ground, we found the remains of the pavement that had been previously opened. The excavations were then continued under my direction for about a month, and at the end of that time the remains of a villa of no inconsiderable extent were exposed. During the progress of the work a great quantity of broken pottery, flanged and striated flue tiles, roofing slabs and charcoal, besides numerous fragments of stucco of various coloured patterns, were brought to light. A few plaster mouldings, some copper roofing-nails, two or three bits of a coloured glass lachrymatory, and some copper coins of the Constantine family, were also found. The walls were built chiefly of the stone of the neighbourhood, in coursed rubble work, and varied from three feet to one foot in thickness.

I shall now proceed to describe the various rooms and portions of the villa, according to the numbers on the plan, corresponding with the order in which they were excavated. 
The apartment which was first opened proved, on examination, to have retained only one or two small fragments of the borders of the pavement previously exhumed (fig. 1). No idea could be obtained of the rich mosaic which formed the centre, the whole of this part being a confused mass of loose tesseræ and cement. From the descriptions of those persons in the neighbourhood who visited the pavement in 1838, it appears that the design consisted of a chariot, with a charioteer, and four horses abreast. Some persons in the parish remembered seeing an inscription or word above the chariot, which the parish clerk told me was either SERVIVS or SEVERVs, but this I found no one could confirm.

The outer border of the pavement, which was two feet wide, was composed of white tesseræ about one inch square ; immediately within this was a narrow guilloche border about five inches wide, composed of blue, red, and white tesseræ, $\frac{3}{8}$ inch square, inside which, at the N.E. and S.W. angles, fragments of a kind of wheel pattern (blue and red upon a white ground) could, after some difficulty, be traced. There were no flues under this apartment, but a sleeper wall, shown dotted on the plan, crossed the western end. The walls of this apartment were so entirely razed that the position of the doorway could not be determined. At this point of the excavations. I was suddenly called away, and, on returning two or three weeks after to the scene of our labours, I heard with regret that in 1838 three labourers had been employed by Mr. Perren to dig for further remains, but without success. It was therefore with anything but sanguine expectations that I directed the labourers to dig northwards, and was agreeably surprised when at about 14 inches below the surface they came to a remarkably perfect pavement, measuring inside the walls $15 \mathrm{ft} .4 \mathrm{in}$. by $17 \mathrm{ft} .8 \mathrm{in}$. This room (fig. 2) was apparently entered by a doorway in the middle of the south wall. One rather peculiar feature in this room was the stone curb indicated in the plan, the inside of which had decidedly been subject to the action of fire. Mr. Heathcote supposes this to have been a fireplace. It is true no hypocaust was found, but the size and position of the curb, as well as what we know of the habits of the Romans, would throw some doubt upon this supposition. The pavement of this room was anything but pleasing in effect, from the great preponderance of blue 
tesseræ, and the repetition of fret-work ; the double guilloche or ribbon pattern at the upper end of the room, and the remarkably wide outer border composed of the large white inch-square tesseræ, tend somewhat to relieve this monotony. The furnace-chamber (fig. 3) was constructed of large stones, which, from the action of the fire, had very much the aspect of very large blue pebbles; the communication between this and the hypocaust (fig. 4) had its sides constructed with bricks an inch thick, whilst the top and bottom of the aperture were of hard stone. In excavating the hypocausts no tesseræ of any description were discovered, although the circular ends were plastered with precisely the same kind of cement used in the bath of a villa discovered at the neighbouring village of Box, where it was embedded with white tesseræ. The pillars, all of which existed in situ, were constructed of a hard red stone, in slabs about an inch thick, and varying from 10 to 12 inches square; the most perfect pier measured about 27 or 28 inches in height. From the second hypocaust (fig. 5) a passage cased with stone, similar to that used in the furnace, and which, like that, had materially suffered from the action of fire, communicated with the chamber (fig. 6). Here two features present themselves to our notice ; viz., the position of the drain in the east wall, and the steps in the south-west corner. Returning to the first hypocaust, we find that the only entrance to the chamber or bath above was from the passage (fig. 7), and that the floor of the bath-room was one or two steps below the passage pavement, as was evinced by the stone step with the tesseræ upon it still existing. In this passage, and in the small room in connection with it, another tesselated pavement was discovered, of which a representation has been preserved, taken from actual measurement. The arrangement of this parement is almost of itself sufficient to indicate that this apartment was the dressing-room, separated only from the passage by a curtain suspended between the piers. But the purposes for which the two small compartments (figs. 8 and 9) were constructed, are by no means so evident. Similar in size and character to those at Bartlow, discovered by the Hon. R. C. Neville, ${ }^{1}$ and concerning the use of which that able archaeologist felt some uncertainty, they demand particular attention. The first of these chambers (fig. 8) was

1 Described in the Arch. Journ., vol. x., p. 17. 
in the form of a recess, having had a pavement in continuation of, or rather in juxtaposition with, that of the dressingroom. Two small fragments only of this pavement existed, but enough to show that the design consisted of the double guilloche or ribbon pattern, bordered by large blue tesseræ. But the singularity which attaches itself to this recess lies mainly in the cavity constructed at its further end. This receptacle, which ran about 15 inches into the foundation of the outer wall, is 2 feet 1 inch below the level of the pavement, and built perfectly water-tight, with stone drains communicating with it from the exterior as well as from the interior. This feature in its arrangement would to some extent point out the purpose for which it was used, but the small size of the cavity, and the difference of level between the two drains, that towards the room being the lowest, make it, however, a matter of some uncertainty. The second of these compartments is still more puzzling ; the dimensions would seem to preclude the probability of its being a bath; another objection may be made against this supposition, as well as any purpose connected with water, from the fact of the floor being constructed of two stones by no means watertight. The sides were, however, thickly plastered, and, when first exposed, the mortar was so hard that the pickaxe would scarcely penetrate it. These circumstances, considered with the seat-like projection on one of its sides, may give rise to a question whether it was not appropriated to the slave in attendance upon the bath. There is still another peculiarity in this part of the villa that remains to be noticed; viz., the short branch drain A B. Its fall, which was very slight, was from east to west, and from a portion discovered in excavating the chamber (fig. 6), it appeared to have projected beyond the wall interiorly; the main drain with which it communicates fell in the same direction, and, after traversing more than 100 feet towards the south-west, terminated in a sort of cesspool hollowed out of the rock. Remains of foundation walls adjoined this, and it was here that the greater number of the coins were found. In the room numbered 10 on the plan, the sleeper walls and passages for hot air were to be seen; the pavement had been destroyed, but a few loose fragments of the tesseræ were found in the flue on the west side of the chamber. The only apparent entrance to this apartment was from the room (fig. 2). The herring-bone masonry of

voL. XiII.

Z Z 
one of the transverse sleeper walls, and the somewhat singular termination of the building northwards, deserve attention.

The remaining portions of the villa require but little comment. The huge paving-stones in the central court (fig. 11), the flues at the S.W. angle, and the drain, $\mathrm{M} \mathrm{N}$, as far as is shown on the plan, had been left quite undisturbed. It is cut out of solid stone, and from the absence of all kind of covering appears to have acted simply as a surface drain. The chambers on the east side of the building were merely marked by the two lower courses of the foundation walls, and call for no further remark.

There is little doubt that more extensive remains might be discovered, for several vestiges of masonry have been brought to light by the plough, subsequently to the excavations which I have described. It must be a matter of great regret that these vestiges of a villa presenting more than ordinarily perfect and interesting features, should, through the apathy and indifference evinced both by the proprietor and occupier of the land, have been hidden from view, shortly after the discovery, and the ground has again been subjected to the plough.

EDWARD WILLIAM GODWIN. 